\title{
PENGATURAN HUKUM PENYELESAIAN PERKARA MELALUI AKTA VANDADING (STUDI PUTUSAN No. 8/PDT.G/2018 PN TANJUNGBALAI)
}

\author{
Oleh: \\ Bahmid ${ }^{1)}$, \\ Irda Pratiwi ${ }^{2)}$, \\ dan Ayu Wandira Marpaung ${ }^{3)}$ \\ Universitas Asahan 1,2,3) \\ E-mail: \\ bahmid1979@gmail.com ${ }^{1)}$, \\ irdanasty@ymail.com $^{2)}$, \\ dan Ayuwandiramarpaung94@gmail.com ${ }^{3)}$
}

\begin{abstract}
Peace occurs when one of the parties, making a joint agreement, does not carry out an achievement that has been agreed as outlined in a memorandum of agreement made in writing or not in writing form. If the achievement is harmed by one of the parties by not implementing an achievement, then a default arises. Default arises when the parties violate a provision of $1320 \mathrm{BW}$ which is the main condition for the occurrence of an agreement and carry out a form of achievement. In this paper, a normative juridical research method was used that takes a case approach in it. The issue raised by the author is How to Regulate the Peace of Debt Based on the Applicable Law and How the Application of the Peace of Debt through the Vandading Deed (Decision Study No. 8 / Pdt.G / 2018 / PN Tanjungbalai). In this study it can be concluded that in settling accounts receivable debts can be mediated and the court can settle peace through the Vandading deed.
\end{abstract}

Keywords: Legal arrangements; case settlement; peace through Vandading deed.

\begin{abstract}
ABSTRAK
Perdamaian terjadi ketika salah satu pihak, yang membuat perjanjian bersama, tidak melaksanakan prestasi yang telah disepakati sebagaimana diuraikan dalam nota kesepakatan yang dibuat secara tertulis atau tidak dalam bentuk tertulis. Jika pencapaian tersebut dirugikan oleh salah satu pihak dengan tidak menerapkan prestasi, maka akan muncul default. Default muncul ketika para pihak melanggar ketentuan 1320 BW yang merupakan kondisi utama untuk terjadinya perjanjian dan melakukan bentuk prestasi. Dalam tulisan ini, metode penelitian yuridis normatif digunakan yang mengambil pendekatan kasus di dalamnya. Masalah yang diangkat oleh penulis adalah Bagaimana Mengatur Kedamaian Hutang Berdasarkan Hukum yang Berlaku dan Bagaimana Penerapan Kedamaian Hutang melalui Perbuatan Vandading (Studi Keputusan No. 8 / Pdt.G / 2018 / PN Tanjungbalai). Dalam penelitian ini dapat disimpulkan bahwa dalam menyelesaikan piutang, piutang dapat dimediasi dan pengadilan dapat menyelesaikan perdamaian melalui akta Vandading.
\end{abstract}

Kata kunci: Pengaturan hukum; penyelesaian kasus; perdamaian melalui perbuatan Vandading. 


\section{PENDAHULUAN}

Hutang piutang adalah suatu perjanjian atau perikatan antara kedua belah pihak untuk saling mengikatkan diri, dimana pihak yang satu memberikan sebuah pinjaman dan pihak yang lainsebagai yamg menerima pinjaman (hutang) yang pemgembalian hutangnya itu telah di tentu dalam jangka waktu tertentu yang dimuat dalam akta perjanjian (Gatot Supramono, 2013:9). Hutang piutang merupakan salah satu perjanjian dalam jenis perjanjian pinjam meminjam yang telah diatur dalam BAB ke tiga belas buku ke tiga di dalam Kitab Undang-Undang Hukum Perdata (KUHPerdata) yang termuat dalam pasalnya yang ke 1754 KUHPerdata yang berbunyi mengenai bahwa pinjam habis pakai adalah perjanjian, dimana pihak pertama sebagai yang menyerahkan sejumlah barang yang dapat dihabiskan oleh pihak kedua namun dengan persyaratan pihak kedua akan mengembalikan sejumlah barang tersebut dalam keadaan dan jumlah yang sama dalam waktu yang telah ditentukan dalam perjanjian yang telah dibuat.

Dalam hukum positif di Indonesia untuk mengatasi pihak dibitur yang malas atau lalai dalam melunasi hutangnya, yaitu dengan cara mengingatkan pihak debibur. Dalam hukum positif di Indonesia, peringatan ini dikenal dengan somasi, hal ini dilakukan secara tertulis sebagaimana pasal 1238 dilakukannya oleh seorang juru sita dari pengadilan. Debitur yang lalai, maka kriditur berhak mengajukan permintaan kepada pengadilan bahwasanya dibitur tidak dapat memenuhi kewajibannya sebagaimana disebutkan dalam pasalnya yang ke 1266 KUHPerdata yang mengenai bahwa di dalam perjanjian hutang piutang syarat batal akan selalu dimuat atau dicatumkan dalam persetujuan yang timbalbalik, bilamana salah satu pihak tidak memenuhi kewajibannya setelah perjanjian dibuat. Walaupun demikian, persetujuan tidak langsug atal demi hukum namun harus memalui proses dipengadilan dan pihak yang merasa dirugiakan harus melakukan permintaan terlebih dahulu ke pengadilan (R. Subekti, 296).

Mengenai kewajiban seseorang dibitur memenuhi suatu hutang dalam hukum positif tersirat pada pasal $1763 \mathrm{BW}$ bahwa seseorang yang telah menerima pinjaman sesuatu barang dari orang lain diwajibkan untuk mengembalikannya dalam jumlah dan keadaan yang sama serta pada waktu yang ditentukannya. Dalam hukum positif di Indonesia, selama hutang itu belum dibayar atau dilunasi, maka kewajiban membayar itu masih ada bilamana sampai terjadi wanprestasi, maka menurut pasal 1243-1252 BW, orang tersebut dapat dipaksa dan dikenai sanksi (Salim, HS, 181).

$$
\text { Dalam menyelesaikan }
$$

permasalahan hukum ini juga dapat dilakukan diluar pengadilan sekalipun kasus tersebut telah masuk kasusnya didalam pengadilan karena dalam proses persidangan perkara prdata majelis hakim haruslah berupaya pada dasarnya mendamaikan kedua belah pihak yang sedang berpekara.Hal ini termuat dalam Surat Edaran Mahkamah Agung RI Nomor 1 tahun 2002 yaitu bahwa semua hakim yang menyidangkan suatu perkara di pengadilan dengann sungguh-sungguh agar mengusahakan perdamaian dengan menerapkan berdasarkann ketentuan dalam pasalnya yang ke $130 \mathrm{HIR} / \mathrm{RBG}$, yang tidak hanya sekedar formalitas melakukan perdamaian semata.

Hakim yang telah ditunjuk merupakan fasilitator yang kemudian membantu ke dua belah pihakutuk berdamai yang pada dasarnya memberikan baik itu dalam bentuk waktu, tempat perdamaian dan pengumpulan data beserta argumentasi-argumetasi parapihak yang 
sedang berpekara.Apabila para pihak yang berpekara menginginkan hakim yang telah di tunjuk sebagai fasilitator menjadi mediator maka hakim tersebut dapat bertindak sebagai mediator dalam menyelesaikan pokok persoalan yang lagi dihadapi para pihak. Hakim tersebut dapat mencoba menyusun proposal perdamaian yang kemudian di konsultasikan kepada para pihak yang berpekara guna dalam menemukan titik keinginan para pihak untuk menemukan hasil yang menguntungkan kedua belah pihak yang berpekara tersebut.

$$
\text { Hakim tersebut dalam }
$$

melaksanakan tugasnya sebagai fasilitator atau mediator diberikan waktu selama tiga bulan oleh ketua pengadilan negeri yang bersangkutan namun itu tidak termasuk dalam waktu penyelesaina perkara berdasarkan dalam Surat Edaran Mahkamah Agung RI Nomor 6 Tahun 1992 (SEMA RI No.6/1992). Dalam hal ini juga hakim yang ditunjuk sebagai fasilitator atau mediator oleh para pihak tidak dapat menjadi hakim majelis dalam perkara yang bersangkutan, untuk menjaga objektifitasnya persidangan di pengadilan.

Berdasarkan dari latar belakang diatas maka rumusan masalah dalam penelitian ini adalah sebagai berikut :

1. Bagaimana Pengaturan Hukum Perdamaian Hutang Piutang Berdasarkan Hukum Yang Berlaku.

2. BagaimanaPenerapan Perdamaian Hutang Piutang Melalui Akta Vandading(Studi Putusan No. 8/Pdt.G/2018/PN Tanjungbalai).

\section{METODE PELAKSANAAN}

Metode hukum yang digunakan dalam penulisan ini adalah metode penelitian Yuridis-normatif dengan melakukan pendekatan kasus, artinya bahwa menelaah bahan hukum dengan pendekatan terhadap pendekatan kasus menggunakan putusan hakim sebagai sumber bahan hukum (Dyah Ochtorina Susanti, A'an Efendi, 2014:119).

\section{a. Sumber Bahan Hukum}

Dalam penulisan ini maka sumber bahan-bahan hukum yang akan diperlukan dalam penelitian ini adalah sebagai berikut:

\section{b. Bahan Hukum Primer}

Bahan hukum primer, yaitu bahanbahan hukum yang mengikat yaitu :

a. Undang-Undang Dasar Tahun 1945.

b. Kitab Undang-Undang Hukum Perdata.

c. Studi Putusan Nomor 8/Pdt.G/2018/PN Tanjungbalai

\section{c. Bahan Hukum Sekunder}

Salah satu bahan hukum dalam penelitian ini adalah bahan hukum sekunder yang merupakan bahan-bahan yang dipergunakan dalam penelitian yangberupa buku hukum dan buku lainnya yang berkaitan dengan hutang piutang, tulisan paka-pakar hukum, laporan penelitian, skripsi dan tesis.

\section{d. Bahan Hukum Tersier}

Dalam penulisan ini juga diperlukan adanya bahan hukum tersier yang merupakan bahan penunjang dari bahan hukum primer dan sekunder seperti kamus hukum dan ensklopedia.

\section{e. Prosedur Pengumpulan Bahan \\ Hukum}

Dalam bentuk prosedur mengumpulkan bahan hukum diperoleh peneliti dari buku- buku perpustakaan yang berkaitan dengan permasalahan hukum yang diangkat oleh penulis.

\section{f. Analisis Bahan Hukum}

Dalam menganalisis bahan hukum, penulis akan menganalisis secara kualitatif berdasarkan metode penelitian hukum normatif. Tahap awal yang dilakukan penulis adalah dengan mengumpulkan bahan hukum primer dan sekunder lalu akan digunakan dalam rumusan masalah yang telah sebelumnya penulis ketengahkan.Bahan-bahan hukum tersebut 
kemudian akan dianalisis berdasarkan interpretasi atau akan ditafsirkan yang kemudian hasil penafsiran dideskripsikan dan disimpulkan secara dedukatif.

\section{HASIL dan PEMBAHASAN} Peraturan Hukum Perdamaian Hutang Piutang Berdasarkan Hukum Yang Berlaku

\section{a. Perdamaian Menurut KUHP Perdata}

Perdamaian terjadi apabila para pihak yang telah membuat kesepakatan bersama salah satu diantaranya tidak melaksanakan suatu prestasi yang telah disepakati yang dituangkan dalam suatu nota perjanjian yang dibuat secara tertulis maupun tidak tertulis.Apabila prestasi dicederai oleh salah satu pihak dengan tidak melaksanakan suatu prestasi maka timbulah suatu wanprestasi.Wanprestasi yang timbul ketika para pihak melanggar suatu ketentuan $1320 \mathrm{BW}$ yang merupakan syarat utama terjadinya suatu perjanjian serta melaksanakan suatu bentuk prestasi (R. Subekti, pasal 1320).

$$
\text { Berdasarkan pasal }
$$

KUHPerdata, pasal 130 HIR dan pasal 154 RBg dalam upaya mendamaikan para pihak yang bersengketa maka majelis hakim akan membuat putusan perdamaian antara kedua belah pihak tersebut. Dalam pasal-pasal tersebut menurut Abdul Manan ada empat manfaat yang terkandung didalamnya adalah bahwa putusan perdamaian yang dibuat oleh majelis hakim merupakan putusan yang berkekuatan hukum tetap yang sama kedudukannya dengan putusan lain ditingkat penghabisan dan putusan tersebut tidak dapat di bantahkan dengan alasan khilaf mengenai hukum oleh salah satu pihak yang merasa dirugikan.

b. Peraturan Mahkamah Agung RI Nomor 01 Tahun 2008 Tentang Mediasi pengertiam mediasi berdasarkan sistem hukum di indonesia termuat dalam pasal 1 butirnya yang ke 7 Peraturan Mahkamah Agunng Republik Indonesia Nomor 1 Tahun 2008 Tentang Prosedur Mediasi di Indonesia yang berbunyi bahwa mediasi merupakan upaya penyelesaian suatu perkara dengan melakukan perundingan untuk mendapatkan kesepakatan antara kedua belah pihak dengan bantuan pihak lain atau hakim sebagai mediator. Dalam hal ini mediator merupakan pihak yang netral yang tidak memihak salah satu pihak namun berupaya menyelesaikan perkara ini dalam bentuk perdamaian dengan cara perundingan agar para pihak dapat berdamai dan pihak mediator tidak boleh menggunakan cara memutuskan secara sepihak saja namun harus bersama-sama dengan para pihak untuk menyelesaikannya hal ini berdasarkan pasala 1 butir yang ke emam.

Berdasarkan buku yang di ciptakan oleh Gery Goodpastes, menurutnyaMediasi merupakan sebuah proses perundingan penyelesaian perkara sengketa yang mana suatu pihak luar misalnya hakim yang telah ditunjuk yang sifatnya netral tanpa memihak salah satu pihak yang bekerja bersama dengan para pihak yang sedang bersengketa guna untuk membantu para pihak yang bersengketa dalam mencapai suatu hasil kesepakatan yang memuaskan para pihak yang sedang berpekara(Gery Goodpastes, 1999:241). Menurut Joni Emirzo mediasi adalah suatu upaya penyelesaian perkara sengketa ke dua belah pihak dengan melakukan kesepakatan bersama melalui mediator yang telah ditunjuk yang sifatnya netral dan tidak boleh membuat suatu keputusan atau kesimpulan bagi ke dua belah pihak karna itu diluar dari kewenangannya sebagai mediator akan tetapi menunjang fasilitator agar terlaksananya suatu dialog antar kedua belah pihak dengan bentuk keterbukaan, 
kejujuran dan tukar pendapat supaya tercapainya mufakat (Joni Emirzon, 2001:69).

Dalam penyelesaian perkara mediasi adalah salah satu bentuk alternatif penyelesaian sengketa diluar pengadilan atau biasa disebut non-liltigasi yang membuat ke dua belah pihak mendapatkan keuntungan yang lebih dari pada menggunakan proses litigasi atau didalam persidangan. Dengan adanya mediasi oleh kedua belah pihak lebih sedikit menderita kerugian, karna apabila menggunakan proses litigasi maka salah satu pihak yang kalah akan merasakan kerugian yang sangat besar. Ke dua belah pihak yang berpekara juga dapat memilih sendiri mediator yang akan membantu mereka dalam penyelesaian perkara, dalam hal ini terkait dengan faktor psikologi ke dua belah pihak, yaitu apabila mereka sama-sama menunjuk dan dapat menerima keberadaaan mediator dan juga mereka percaya akan kenetralan mediator maka mereka akan lebih melasanakan hasil mediasi dengan kesukarelaan sehingga permasalahannya dapat diselesaikan dengan cepat.Suatu Penyelesaian perkara melalui pengadilan (litigasi)adalah bersifat formal, memaksa ke dua belah pihak, bercirikan pertentangan didalamnya, dan berdasarkan hak-hak.

\section{c. Capaian Pelasakanaan Mediasi}

Dalam penyelesaian perkara melalui proses litigasi atau di dalam persidangan maka tujuan utamanya adalah untuk menentukan yang mana salah satu pihak yang akan kalah dan pihak mana yang menang berdasarkan alat bukti yang dihadirkan oleh kedua belah pihak. Dalam hal ini sangat berbeda dengan tujuan yang ingin dicapai dalam proses mediasi yaitu sebagai berikut:

1. Di lakukannya mediasi supaya dapat menghasilkan suatu perundingan atau kesempakatan yang dapat di terima oleh kedua belah pihak.

2. Di lakukannya mediasi bertujuan untuk mempersiapkan kedua belah pihak yang bermasalah untuk menerima semua konsekuensi dari keputusan-keputusan yang mereka buat.

3. Tujuan dari mediasi adalah untuk mengurangi kekhawatiran dan dampak negatif lainnya dari suatu konflik yang terjadi dengan cara membantu kedua belah pihak yang bersengketa untuk mencapai suatu penyelesaian secara konsesus.

Sejak tahun 2003 mediasi telah di perkenalkan di Indonesia melalui proses pada lembaga peradilan. Pemerintah telah berupaya mengeluarkan peraturan Mahkamah Agung (Perma) No. 3tahun 2003 tentang Prosedur Mediasi di Pengadilan Mahkamah Agung Republik Indonesia. Perma ini dilatar belakangi dari adanya realita sosial yang mana pada saat itu pengadilan sebagai lembaga yang diharapkan mampu untuk menyelesaikan suatu perkara namun tidak mampu dalam menyelesaikanya berdasarkan dengan asas cepat dan biaya ringan yang menjadi patokan di bentuknya pengadilan. Banyaknya perkara yang menumpuk dipengadilan karna proses yang lama membuat para pihak yang berpekara lama mendapatkan ke pastian hukum dari kasus yang lagi dihadapinya. Maka diperkenalkanlah mediasi yang mampu menyelesaikan perkara para pihak guna mempercepat adanya kepastian hukum bagi para pihak yang berpekara sehingga kasus tersebbut cepat terselesaikan dan membuat para pihak dapat dapat berdamai dan saling mengutungkan ke duanya.

Pada hakikatnya Penyelesaian perkara dengan cara perdamaian (Mediasi) telah diperkenalkan dalam sistem hukum yang berlaku di Indonesia pada saat 
pemerintahan Hindia belanda pada saat itu melalui Reglement op de burgerlijke rechtvordering $(\mathrm{RV})$.Pada masa pemerintahan BJ Habibie dikeluarkannya Undang-Undang No. 30 Tahun 1999 Tentang Arbirase dan Alternatif Penyelesaian Sengketa yang bertujuan untuk membuat para pihak yang berpekara dapat lebih menunjukan maksud keinginan dari permasalahan yang sedang dihadapi melalui adanya proses perdamaian.

\section{Penerapan Perdamaian Hutang Piutang Studi Putusan No 8/Pdt.G/2018/PN Tanjung Balai}

Di Indonesia ada dasar hukum yang memperbolehkan suatu sengketa diselesaikan melalui mekanisme alternatif penyelesaian sengketa yaitu Undang Undang No. 30 Tahun 1999 tentang Arbitrase dan Alternatif Penyelesaian Sengketa. Juga dalam Kitab Undang Undang Hukum Perdata pada Pasal 1851 menegaskan bahwa perdamaian dapat dilakukan atas perkara yang telah ada baik yang sedang berjalan di pengadilan maupun perkara yang akan diajukan ke pengadilan. Hal tersebut dimungkinkan dan sah adanya sepanjang para pihak bersedia dan mempunyai itikad baik untuk menyelesaiakan suatu masalah.

Dalam hal perdamaian tersebut baik yang dilakukan oleh hakim sebagai mediatorfasilitator juga perdamaian yang dilakukan di luar pengadilan maka keduanya akan dilakukan secara tertulis, untuk menguatkan perdamaian tersebut. Dalam Pasal 1851 Kitab Undang-undang Hukum Perdata menyebutkan bahwa : Perdamaian adalah suatu perjanjian dimana kedua belah pihak, dengan menyerahkan, menjanjikan atau menahan suatu barang.Mengakhiri suatu perkara yang sedang bergantung ataupun mencegah timbulnya suatu perkara. Perjanjian tidak sah melainkan jika dibuat tertulis.
Berdasarkan hal tersebut, perjanjian perdamaian yang dihasilkan dari suatu proses penyelesaian sengketa harus dituangkan dalam bentuk tertulis, hal tersebut bertujuan untuk mencegah munculnya kembali sengketa yang sama di kemudian hari. Untuk memenuhi hal tersebut di atas maka proses perdamaian di luar pengadilan dapat dilaksanakan dengan membuat suatu akta yaitu akta perdamaian.Akta perdamaian ini dapat berupa akta di bawah tangan maupun akta otentik yang dibuat oleh seorang notaris.

\section{Akibat Hukum Acte Van Dading}

Banyak hakim lebih cenderung menggunakan Acte Van Dading untuk Akta perdamaian yang dibuat oleh para pihak tanpa/belum ada pengukuhan dari hakim dan Acte Van Vergelijk adalah akta yang telah memperoleh pengukuhan dari hakim. Perdamaian pada hakikatnya dapat saja dibuat para pihak dihadapan atau oleh hakim yang memeriksa perkarajuga perdamaian dapat dibuat oleh para pihak diluar pengadilan dan selanjutnya dibawa ke pengadilan yang bersangkutan untuk dikukuhkan (Puslitbang, 164).

Dari hal tersebut di atas maka dapat disimpulkan bahwa perdamaian dapat dibagi 2 yaitu sebagai berikut:

1. Akta perdamaian yang dibuat dengan persetujuan dari hakim, yang mana akta tersebut dibuat oleh kedua belah pihak yang berpekara dihadapan hakim atau dengan mediator maupun fasilitator atau yang sering disebut dengan Acte Van Vergelijkproses ini merupakan proses yang memang dihadirkan dipengadilan sebelum perkara sengketa dibacakan.

2. Akta perdamaian tanpa persetujuan hakim yaitu yang dilakukan dengan Alternatif Penyelesaian Sengketa (APS) atau yang biasa disebut juga Alternative Dispute Resolution (ADR)dengan menggunakan Acta 
Van Dading maupun akta di bawah tangan yang mana mediator sebelumnya telah di tentukan oleh kedua belah pihak yang berpekara secara bersama-sama.

\section{Kekuatan Hukum Acte VanDading}

Dalam kekuatan hukum acte vandading adanya kepastian hukum yang merupakan perlindungan secara Yustisiabelterhadap tindakan kesewenangwenangan, yang artinya bahwa seseorang yang sedang berpekara mendapatkan sesuatu hal yang dapat dipasktikan oleh hukum sesuai yang diharapkan. Maka dalam hal ini perlu suatu kajian hukum secara lebih mendalam dan menyeluruh mengenai akta perdamaian sebagai bentuk upaya dalam penyelesaian perkara yang menjadi kewenangan dari Notaris sebagai pembuat akta otentik dalam putusan pengadilan dan tidak boleh terjadi dua kali pemutusan terhadap satu kasus berdasarkan dari asas Judicata Habitur. Sehingga akta Acte Van Dading telah memiliki kekuatan hukum tetap berdasarkan asas Judicata Habitur dan tidak dikenal lagi upaya hukum lain seperti banding serta kasasi.

\section{KESIMPULAN dan SARAN}

\section{Kesimpulan}

1. Pengaturan Hukum Perdamaian Hutang Piutang Berdasarkan Hukum Yang Berlaku. Peraturan Mahkamah Agung Republik Indonesia nomor : 01 tahun 2008 Tentang Prosedur Mediasi di Pengadilan, dimana dalam Peraturan Mahkamah Agung Nomor 01 tahun 2008 telah mengatur tahapan mediasi.

2. Penerapan Perdamaian Hutang Piutang Studi Putusan No. 8/Pdt.G/2018/PN

Tanjungbalai.Banyak hakim lebih cenderung menggunakan Acte Van Dading untuk Akta perdamaian yang dibuat oleh para pihak tanpa/belum ada pengukuhan dari hakim dan Acte Van Vergelijk adalah akta yang telah memperoleh pengukuhan dari hakim, Perdamaian pada hakikatnya dapat saja dibuat para pihak dihadapan atau oleh hakim yang memeriksa perkarajuga perdamaian dapat dibuat oleh para pihak diluar pengadilan dan selanjutnya di bawa ke pengadilan yang bersangkutan untuk dikukuhkan.

\section{Saran}

1. Pengaturan Hukum Perdamaian Hutang Piutang Berdasarkan Hukum Yang Berlaku yaitu perlunya suatu norma hukum yang baru yang mengatur secara tegas dan jelas mengenai perjanjian hutang piutang. Serta apabila dikemudian hari teijadi permasalahan maka akan mudah dan cepat proses penyelesaiannya. Karena selalu dalam menyelesaikan perkara perdata dalam hal masalah hutang piutang akan memakan waktu yang lama dalam penyelesaiaannnya.

2. Penerapan Perdamaian Hutang Piutang Studi Putusan No. 8/Pdt.G/2018/PN Tanjungbalai setiap perdamaian yang dituangkan haruslah dipatuhi semua para pihak tanpa terkecuali yang bertujuan dalam menghormati isi putusan akta vandading tersebut. Karena akta vandading tersebut merupakan akta kesepakatan yang dituangkan dan disepakati bersama. 


\section{DAFTAR PUSTAKA}

\section{a. Buku}

Gatot Supramono,2013,Perjajicm Utang Piutang, Jakarta.

R.Subekti,Kitab Undang-undang Hukum Perdata.

Salim HS, Pengantar Hukum Perdata Tertulis BW .

R.Subekti, Kitab Undang-Undang Hukum Perdata.

Gary Goodpastes, 1999, Pandnan Negosiasi dan Mediasi, Elips, Jakarta.

Joni Emirzon, 2001, Alternatif Penyelesaian Sengketa di Luar Pengadilan, Gramedia Pustaka Utama, Jakarta.

Retnowulan Sutantio, 2003, Mediasi dan Dading, Proceedings Arbitrase dan Mediasi, (a) cet. 1, Jakarta : Pusat Pengkajian HukumDepartemen Kehakiman dan Hak Asasi Manusia.

M.R. Tresna, 1975, Komentar HIR, Jakarta: Pradnya Paramita.

\section{b. Undang-undang}

Peraturan Mahkamah Agung Nomor 01 Tahun 2008 Tentang Mediasi,pasal 1 butir 6-7.

Surat Edaran Mahkamah Agung Republik IndonesiaNo. 6 Tahun 1992 